\title{
Sphingomonas paucimobilis: An Uncommon Cause of Meningitis
}

\author{
Sphingomonas paucimobilis: Az Rastlanan \\ Bir Menenjit Etkeni
}

\author{
Nazlı Deveci', Nazlı Gürkan², Nurşen Belet ${ }^{1}$, Serpil Uğur Baysal' \\ 'Department of Pediatrics, Dokuz Eylul University School of Medicine, Izmir, Turkey \\ ${ }^{2}$ Department of Medical Microbiology, Dokuz Eylul University School of Medicine, Izmir, Turkey
}

\begin{abstract}
Sphingomonas paucimobilis is a gram-negative bacillus. It is widespread in nature and in hospital environments; but it hardly causes life-threatening infections. In this report, a case of community- onset bacterial meningitis in an adolescent patient was presented. A previously healthy, 14-year old boy attended to our hospital with fever of two days, headache and vomiting. Based on the patient's history, physical examination signs and laboratory results, he was hospitalized with the diagnosis of acute bacterial meningitis. The aerobic bacterial culture of the CSF yielded yellow pigmented, slow growing, oxidase and catalase positive colonies after 48 hours of incubation on Columbia sheep blood agar plates. The isolate was identified as S. paucimobilis by two identification systems. The patient recovered with no sequela. In the literature, there are very few reported cases of meningitis caused by S. paucimobilis. This agent can cause severe meningitis.
\end{abstract}

Keywords: Meningitis, bacterial, child, adolescent, Sphingomonas paucimobilis

\section{Introduction}

Sphingomonas, which was first identified in 1977 as Pseudomonas paucimobilis, is an aerobic, non-fermentative, oxidase and catalase positive, slow moving gram-negative bacillus (1). This microorganism can be found in soil, medical equipment

\begin{abstract}
Özet
Sphingomonas paucimobilis, gram-negatif bir çomaktır. Doğada ve hastane ortamında yaygın olarak bulunur; pek az olguda hayatı tehdit eden enfeksiyonlara yol açmaktadır. Bu bildiride, S. paucimobilis'in etken olduğu, bakteriyel menenjit gelişen bir adolesan olgu sunulmuştur. Daha önce sağlıklı, 14 yaşında erkek lise öğrencisi, iki gündür süren ateş, baş ağrısı ve kusma yakınmaları ile hastanemize başvurdu. Öykü, fizik muayene ve laboratuvar bulguları temelinde akut bakteriyel menenjit tanısı ile servise yatırıldı. Beyin omurilik sıvısı (BOS) örneğinin aerop kültürü, Columbia koyun kanlı agar plağında 48 saatlik inkubasyondan sonra, sarı pigmentli, yavaş büyüyen, oksidaz ve katalaz reaksiyonları pozitif koloniler üredi. İzolat, iki ayrı bakteri identifikasyon sistemi ile S. paucimobilis olarak tanımlandı. Olgu, iki hafta süren tedavinin sonunda sekelsiz iyileşti. Literatürde, pek az olguda bakteriyel menenjit etkeni olarak S. paucimobilis bildirilmiştir. Bu etken, ağır menenjite yol açabilmektedir.
\end{abstract}

Anahtar Kelimeler: Bakteriyel menenjit, çocuk, adolesan, Sphingomonas paucimobilis

and tools, in contaminated liquids and the respiratory assist devices in the hospital. It can cause bacteremia and sepsis most frequently, but also pneumonia, peritonitis, urinary system infections, catheter associated infections and soft tissue infections $(2,3)$. It can lead to infection in both immune competent and the immune suppressed individuals. This bacteria 
has been especially associated with the water supply system of the hospitals and has been reported to lead to epidemics in immune-suppressive patients in the hematology and oncology units (4). Besides being a cause of life-threatening infections, it is a microorganism of low virulence (5).

There are very few meningitis cases associated with this agent in the literature $(3,6,7)$.

In this report, a case of bacterial meningitis caused by $S$. paucimobilis is presented in a previously healthy adolescent patient .

\section{Case Report}

A previously healthy, 14.5-year-old male, high school student (born on 15 June 2001; hospitalized on 7 January 2016) attended to our hospital with fever of two days, headache and vomiting. He was the third son of a farmer family living in the rural region of the Aegean Region of Turkey. The patient's medical history revealed that his vaccinations were complete, he had no underlying disease, and that he had no prior hospitalization. He had no history of trauma before admission. His weight with respect to height was 98\%; the Body Mass Index was 19.3.

In the physical examination on admission, his body temperature was $38.7^{\circ} \mathrm{C}$, he was lethargic, deep tendon reflexes were hyperactive and meningeal irritation findings were positive. With the preliminary diagnosis of meningitis, a lumbar punction was performed. The CSF analysis findings were as follows: turbid color, increased pressure, cell count: $1080 / \mathrm{mm}^{3}$, $90 \%$ polymorphonuclear leukocytes; protein $401 \mathrm{mg} / \mathrm{dL}$, glucose $<10 \mathrm{mg} / \mathrm{dL}$ (concominant blood sugar $163 \mathrm{mg} / \mathrm{dL}$ ). $\mathrm{Hb}$ was $11.7 \mathrm{~g} / \mathrm{dL}$; WBC was 32.000/. $\mathrm{mm}^{3}$; CRP was $252 \mathrm{mg} / \mathrm{L}$. The CSF sample was taken aseptically. Upon the establishment of the diagnosis of bacterial meningitis, dexamethazone $(0.15$ $\mathrm{mg} / \mathrm{kg}, 4$ doses) was started 20 minutes before antibiotherapy. Vancomycin (60 mg/kg/day, 4 doses), ceftriaxone (100 mg/ $\mathrm{kg} /$ day, in 2 doses) treatment was started.

The aerobic bacterial culture of the CSF yielded yellow pigmented, slow growing, oxidase and catalase positive colonies on Columbia sheep blood agar plates after 48 hours of incubation. The isolate was identified as Sphingomonas paucimobilis by using two different bacterial identification systems: Vitek2 Compact System, with Gram Negative identification card (bioMerieux, France), 97\% probability and 'Perfect Identification' safety level; BBLTM CrystalTM (BD, ABD), 'Sphingomonas paucimobilis, Positive Identification, $99.8 \%$ probability, typical biotype. The antimicrobial susceptibility of the isolate was determined by standard disk diffusion test by using disks of amikacin, gentamicin, tobramycin, imipenem, meropenem, ciprofloxacin, ceftazidime, sulbactam/cefoperazone, piperacillin, piperacillin/tazobactam and it was found to be sensitive to these antibiotics. The minimum inhibitor concentration (MIC) value of the isolate for cefotaxime was found to be $0.06 \mu \mathrm{g} / \mathrm{mL}$. Since there is no existing standard susceptibility breakpoint determined for S. paucimobilis, the susceptibility evaluation of the isolate was made according to the CLSI standards determined for Pseudomonas aeruginosa $(8,9)$. The real-time PCR results of the CSF sample for enterovirus, adenovirus, herpes simplex virus type 1 and Mycobacterium tuberculosis complex was found to be negative. Acid resistant staining was negative. PPD was assessed as $0 \mathrm{~mm}$. In serological examination, the HIV test was negative. There was no microbial growth in the blood culture. In the cranial MR imaging, meningeal contrasting was observed in the frontal region, T2 signal increase and paranasal sinuses were assessed as parasinusitis due to mucosal thickening and leveling secondary to infection.

During clinical follow-up, the general condition of the patient recovered after 48 hours; fever and meningeal irritation findings regressed. When the results of the culture and antibiogram were available, vancomycin administration was stopped and the treatment continued with ceftriaxone. No hearing loss was detected in audiological examination. Antibiotic treatment was completed to 14 days and the patient was discharged since his general condition was good and was referred to the Department of Pediatric Infectious Diseases for follow up.

\section{Discussion}

Sphingomonas was first discovered as an infectious agent in humans in 1977 by Holmes et al. and was named as P. paucimobilis (10). In 1979, it was reported to be an agent associated with leg ulcer, septicemia and meningitis, and in 1990, was named as S. paucimobilis by Yabuuchi et al. based on new phylogenetic data $(1,3)$. In the current classification, 94 different Sphingomonas species are classified in the Sphingomonas genus (11).

The members of the Sphingomonadacea family are obligate aerobes, are chemoheterotrophs, and characteristically produce a yellow pigment $(12,13)$.

The Sphingomonas species are bacteria that can be found in a wide spectrum of different environments. They can be isolated from various aquatic environments such as river water, undergroundwater, sea water, from soil, virgin natural environments and also from contaminated environments, even from environments containing toxic and resistant compounds. These bacteria can biologically decompose one or more of the contaminants in a contaminated environment and use them as a single carbon source. They have oligotrophic properties and can live in environments of very low nutrient content. 
Another remarkable characteristic of these bacteria is their capability to metabolize xenobiotic materials such as drugs, insecticides, petroleum products which are foreign to living systems $(14,15)$. With the virtue of their ability to live in chlorinated water and to forma biofilms, they can easily indwell man-made environments (16-18).

Bacteria of Sphingomonadacea family are almost residents in drinking water and utilization water systems of the cities. Vaz-Moreira et al. have carried out a study in 2011 to define the resistance potential of these widespread and potential infectious bacteria and to identify their potential antibiotic resistance phenotypes with 86 isolates. They have identified colistin resistance in $91.9 \%$ of the isolates and it was believed that this is an intrinsic phenotype of the Sphingomonadacea family (19). In $10.5 \%$ of the isolates, multiple resistance phenotype in the form of resistance to three different antibiotic classes other than colistin was detected. This study identified the resistance to beta-lactams, especially ticarcillin, piperacillin, piperacillin-pyocyanin resistances as the most frequent resistance phenotype, at a rate of more than $50 \%$; the second most frequent resistances were identified as fluoroquinolone and sulfonamide resistances.

It has been demonstrated that the Sphingomonas group bacteria can contaminate the sterile water supply systems, distilled water systems of hospitals and it has been speculated that the chlorine in water is also decomposed by these bacteria (20). Because of all these reasons, the distilled water, hemodialysis fluids, sterile medicine preparation solutions can easily be contaminated with Sphingomonas species. When sufficient sterilization of the bacteria can not be ensured by standard sterilization methods, epidemics have been reported (21).

It has been reported that the bacteria of the Sphingomonas genus can also be found in indoor dust as aerosol (22). With this property, it can colonize in mechanical ventilators, catheters, bronchofiberoscopes and other medical tools and equipment (23).

S. paucimobilis may lead to infection in both healthy and immune suppressed individuals. It has been reported that it can cause infections such as bacteremia, catheter associated infection, peritonitis associated with peritoneal dialysis, urinary system infection, biliary system infection, skin infection, ventilator associated pneumonia, menengitis, myositis, osteomyelitis, septic arthritis, endophthalmitis, cervical lymphadenitis, bromhidrosis, gastroenteritis (24). Besides causing life-threatening infections, it is a microorganism with low virulence. It is thought that this is due to the absence of the lipopolysaccharide $A$ in the cell wall of S. paucimobilis, which is a common component of the cell wall of Gram-negative bacteria (5). It is thought that the main factor which determines virulence in S. paucimobilis is the activity of the enzymes
DNAase, acid phosphatase, alkaline phosphatase, esterase and lipase (25). Although community-onset infections are less commonly seen, primary risk factors are diabetes and alcoholism and is frequently observed as bacteremia. A geographical distribution specific to this microorganism could not be determined (26).

There are no strict principles for the treatment of Sphingomonas paucimobilis infections. The S. paucimobilis isolates are generally resistant to penicillin and first generation cephalosporins since they form beta-lactamase of chromosomal origin. Its resistance to third generation cephalosporins and fluoroquinones varies. A study by Cheong et al. reported resistance to cefotaxime and amikacin while Özdemir et al. have reported sensitivity to aminoglycosides, quinolones, trimethoprime/sulfamethoxazole, and cephalosporins other than cefoxitin and ceftazidime $(27,28)$. The isolate reported as the cause of osteomyelitis by Pascale ve arket al. has been determined to be sensitive to amoxicillin/clavulanic acid, cefepime and carbapenems and resistant to amikacin, ceftazidime and fluoroquinolones (29). In the present case, the isolate was found to be sensitive to amikacin, gentamicin, tobramycin, imipenem, meropenem, ciprofloxacin, ceftazidime, sulbactam/cefoperazone, piperacillin, piperacillin/tazobactam; additionally, the cefotaxime MIC value was evaluated $(0.06 \mu \mathrm{g} / \mathrm{mL})$ and found to be sensitive to cefotaxime. These different results show that the treatment should be based on the in vitro tests of the clinical isolates. In a study by Bayram et al. 24 children referring to their hospital between 2005-2012 with S. paucimobilis isolation were examined and it has been reported that half of the cases were community-onset; however, no underlying risk agent could be identified (30). It has been shown that carbapenem treatment was the most effective. In the present case there was also no underlying disease and he applied with community-onset meningitis.

There are few S. paucimobilis cases in the literature. The present case is the first $S$. paucimobilis menegitis reported in the adolescent age group. The first meningitis case was reported by Hajiroussou et al. in 1979; the patient was a 39-year old male, who was being followed up for three years for epilepsy; two days before a headache had started and he had an attack the day he referred to the hospital (3). In his CSF culture $S$. paucimobilis grew and he was treated with ampicillin to which it was found to be sensitive in the antibiogram. The probable transmission was proposed to be via the gastrointestinal system. Another meningitis case was reported by Tai et al. where the patient was a 31-year old male farmer, previously healthy (6). This patient died due to cerebral edema and hydrocephaly due to S. paucimobilis. In his treatment intravenous acyclovir and seftriaxon was used. The transmission was reported as soil; it was concluded that meningitis had developed after 
septicemia since skin integrity had been disturbed due to a wound on the leg. We also considered that the transmission of the agent was via soil but we could not identify a condition to disturb skin integrity. Bolen et al. reported a 39-year old, immune-suppressive female case who was hospitalized due to final stage renal failure and had kidney transplantation from a cadaver (7). Ventriculitis and hydrocephaly developed while she was being treated with acyclovir; in her CSF culture S. paucimobilis, sensitive to meropeneme, growth was found; meropeneme was added to the treatment and the ventriculitis regressed on the $21^{\text {st }}$ day of the treatment. The present case also recovered in the early stage without sequel by appropriate treatment.

S. paucimobilis must be kept in mind as a community-onset infection agent since it is widespread in nature and is resistant to the standard sterilization methods applied to hospital fluids. It is important that the treatment choice be based on antibiogram.

Informed Consent: Written informed consent was obtained from parent of patient.

Peer-review: Externally peer-reviewed.

Author Contributions: Concept - ND, SUB; Design - ND, SUB, NG, NB; Supervision - SUB, NB; Collection and/or Processing: ND, NG, SUB, NB; Analysis and/or Interpretation - ND, NG, SUB, NB; Literature Review- ND, NG, NB, SUB; Writing - ND, NG, SUB; Critical Review SUB, NG, NB.

Conflict of Interest: No conflict of interest was declared by the authors.

Financial Disclosure: No financial disclosure was declared by the authors.

\section{References}

7. Yabuuchi E, Yano I, Oyaizu $H$, Hashimoto $Y$, Ezaki T, Yamamoto $H$. Proposals of Sphingomonas paucimobilis gen. nov. and comb. nov., Sphingomonas parapaucimobilis sp. nov., Sphingomonas yanoikuyae sp. nov., Sphingomonas adhaesiva sp. nov., Sphingomonas capsulata comb. nov., and two genospecies of the genus Sphingomonas.

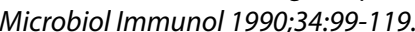

2. Peel M, Davis JM, Armstrong WLH, Wilson RR, Holmes B. Pseudomonas paucimobilis from a leg ulcer on a Japanese seaman. J Clin Microbiol 1979;9:561-4.

3. Hajiroussou AJ, Holmes $B$, Bullas J, Pinning CA. Meningitis caused by Pseudomonas paucimobilis. J Clin Pathol 1979;32:953-5.

4. Kilic $A$, Senses $Z$, Kurekci $A E$, et al. Nosocomial outbreak of Sphingomonas paucimobilis bacteraemia in a hemato/oncology unit. Jpn JInfect Dis 2007:60:394-96.

5. Morrison AJ, Shulman JA. Community-acquired blood stream infection caused by Pseudomonas paucimobilis: case report and review of the literature. J Clin Microbiol 1986;24:853-5.

6. TaIML, Velayuthan RD. Sphingomonas paucimooths: an unusualcause of meningitis -case report. Neurol Med Chir 2014;54:337-40.
7. Bolen RD, Palavecino E, Gomadam A, Balakrishnan N, Datar $S$. Sphingomonas paucimobilis meningitis and ventriculitis in an immunocompromised host. J Neurol Sci 2015;359:18-20.

8. Clinical and Laboratory Standards Institute. Performance standards for antimicrobial disk susceptibility tests; approved standard, 10th ed. Wayne: Clinical and Laboratory Standards Institute, 2009, M2-A10.

9. Clinical and Laboratory Standards Institute. Performance standards for antimicrobial susceptibility testing; Twenty- third informational supplement. Wayne: Clinical and Laboratory Standards Institute, 2013:M100-S23.

10. Holmes B, Owen RJ, Evans A, Malnick H, Willcox WR. Pseudomonas paucimobilis, a new species isolated from human clinical specimens, the hospital environment, and other sources. Int J Syst Bacteriol 1977;27:133-46.

11. List of prokaryotic names with standing in nomenclature. Avaliable from: $h$ ttp://www.bacterio.net/.26.10.2016.

12. Yabuuchi E, Kosako Y. Family I. Sphingomonadaceae Kosako, Yabuuchi, Naka, Fijiwara and Kobayashi 2000b, 1953vp (effective publication: Kosako, Yabuuchi, Naka, Fijiwara and Kobayashi 2000a, 563). In: Brenner DJ, Krieg NR, Staley JT, Garrity GM (eds). Bergey's manual of systematic bacteriology. $2^{\text {nd }}$ ed. The Proteobacteria, part C: The Alpha-, Beta-, Delta-, and Epsilon proteobacteria. New York: Springer, 2005:233-86.

13. Garrity GM, Brenner DJ, Krieg NR, Staley JT (eds). Bergey's manual of systematic bacteriology. Vol 2. New York: Springer, 2004:233-86.

14. Balkwill DL, Fredrickson JK, Romine MF (eds). Sphingomonas and related genera, In: Dworkin M, Falkow S, Rosenberg E, Schleifer KH, Stackebrandt $E$ (eds). The Prokaryotes: an evolving electronic resource for the microbiological community. Vol 1. New York, NY: SpringerVerlag, 2006:605-29.

15. Stolz A. Molecular characteristics of xenobiotic-degrading sphingomonads. Appl Microbiol Biotechnol 2009;81:793-811.

6. Furuhata K, Kato Y, Goto K, et al. Identification of yellow-pigmented bacteria isolated from hospital tap water in Japan and their chlorine resistance. Biocontrol Sci 2007;12:39-46.

17. Hong PY, Hwang C, Ling F, Andersen GL, LeChevallier MW, Liu WT. Pyrosequencing analysis of bacterial biofilm communities in water meters of a drinking water distribution system. Appl Environ Microbiol 2010;6:5631-5.

18. Koskinen R, Ali-Vehmas T, Kampfer $P$, et al. Characterization of Sphingomonas isolates from Finnish and Swedish drinking water distribution systems. J Appl Microbiol 2000;89:687-96.

9. Vaz-Moreira I, Nunes OC, Manaia CM. Diversity and antibiotic resistance patterns of Sphingomonadaceae isolates from drinking water. Appl Environ Microbiol 2011;77:5697-706.

20. Oie S, Oomaki M, Yorioka K, et al. Microbial contamination of 'sterile water' used in Japanese hospitals. J Hosp Infect 1998;38:61-5.

21. Maragakis LL, Chaiwarith $R$, Srinivasan $A$, et al. Sphingomonas paucimobilis bloodstream infections associated with contaminated intravenous fentanyl. Emerg Infect Dis 2009;15:12-8.

22. Andersson AM, Weiss $N$, Rainey F, Salkinoja-Salonen MS. Dust-borne bacteria in animal sheds, schools and children's day care centres. J Appl Microbiol 1999;86:622-34.

23. Lemaitre $D$, Elaichouni A, Hundhausen $M$, et al. Tracheal colonization with Sphingomonas paucimobilis in mechanically ventilated neonates due to contaminated ventilator temperature probes. J Hosp Infect 1996;32:199-206.

24. Ryan MP, Adley CC. Sphingomonas paucimobilis: a persistent Gramnegative nosocomial infectious organism. J Hosp Infect 2010;75:153-7. 
25. Smalley DL. Endotoxin-like activity in Pseudomonas paucimobilis (group llk biotype 1) and Flavobacterium multivorum (group llk biotype 2). Experientia 1982;38:1483-84.

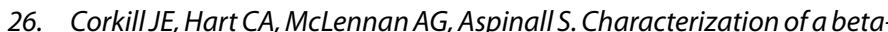
actamase produced by Pseudomonas paucimobilis. J Gen Microbiol 1991:137:1425-9.

27. Gheong HS, WI YAl, Aloon SY, et at. Elinical features and treament putcomes of infections caused by Sphingomonas paucimobilis. Infect

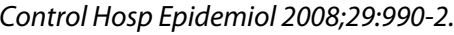

28. Ozdemir M, Pekcan S, Demircili ME, et al. A rare cause of bacteremia in a pediatric patient with Down syndrome: Sphingomonas paucimobilis. Int J Med Sci 2011;8:537-9.
29. Pascale R, Russo E, Esposito I, Leone S, Esposito S. Sphingomonas paucimobilis osteomyelitis in an immunocompetent patient. A rare case report and literatüre review. New Microbiol 2013;36:423-6.

30. Bayram N, Devrim I, Apa H, Gülfidan G, Türkyılmaz HN, Günay I. Sphingomonas paucimobilis infections in children: 24 case reports. Mediterr J Hematol Infect Dis 2013;5:e2013040. 